\title{
Identifikasi Kualitas Fisik Tabung LPG 3 kg menggunakan Blob Detection dan Fitur Warna RGB to $\mathrm{HSV}$
}

\author{
Erwin Yudi Hidayat ${ }^{1}$, Teguh Budi Prasetyo \\ Fakultas Ilmu Komputer \\ Universitas Dian Nuswantoro \\ Semarang, Indonesia \\ e-mail: 1erwin@dsn.dinus.ac.id, ${ }^{2} 111201408202 @$ mhs.dinus.ac.id \\ Diajukan: 9 Agustus 2019; Direvisi: 3 September 2019; Diterima: 25 September 2019
}

\begin{abstract}
Abstrak
Pengguna gas LPG ukuran $3 \mathrm{~kg}$ meningkat setiap tahunnya. Perlu adanya perlindungan agar pengguna merasa aman. Perbaikan fisik tabung LPG $3 \mathrm{~kg}$ dilakukan untuk menjaga kualitas. Dalam proses perbaikan tersebut tabung mempunyai standar kelayakan dari warna, bentuk dan masa edar tabung. Dari segi warna tabung dikatakan layak jika tidak terdapat karat lebih dari $15 \%$. Untuk menghindari subjektivitas, identifikasi kelayakan tabung dapat dilakukan menggunakan Blob Detection dan ekstraksi Red Green Blue (RGB) to Hue Saturation Value (HSV). Metode Blob Detection merupakan metode untuk menghitung hubungan suatu grup piksel sesuai dengan kategorinya. Total citra yang digunakan sejumlah 340 dengan format *.jpg, meliputi 160 citra latih, 60 citra kualitas layak sebelum tabung diperbaiki, 60 citra kualitas layak setelah tabung diperbaiki, serta 60 citra tidak. Diperoleh hasil akurasi 100\% untuk citra kualitas layak setelah tabung diperbaiki, 73,33\% untuk citra tabung kualitas layak sebelum tabung diperbaiki, dan 86,67\% untuk kualitas tidak layak.
\end{abstract}

Kata kunci: Blob Detection, $L P G, R G B, H S V$.

\begin{abstract}
Three-kilogram LPG gas users are increasing every year. Protection is needed so that users feel safe. Physical improvement of $3 \mathrm{~kg} L P G$ cylinders is done to maintain quality. In the process of repairing, the tube has a standar of suitability of color, shape and circulation period of the tube. In terms of the color of the tube is said to be feasible if there is no rust of more than 15\%. To avoid subjectivity, identification of tube viability can be done using Blob Detection and extraction of Red Green Blue (RGB) to Hue Saturation Value (HSV). Blob Detection Method is a method for calculating the relationship of a group of pixels according to their categories. A total of 340 images are used with the format *.jpg, including 160 training images, 60 quality images before the tube is repaired, 60 quality images after the tube is repaired, and 60 images of improper tube images. Obtained results of $100 \%$ accuracy for the tube after repaired, $73.33 \%$ of the tube image before the tube was repaired, and $86.67 \%$ for the improper tube image quality.
\end{abstract}

Keywords: Blob Detection, $L P G, R G B, H S V$.

\section{Pendahuluan}

Pada tahun 2006 pemerintah merencanakan program konversi minyak tanah ke Liquid Petrolium Gas (LPG). PT Pertamina (Persero) menjadi penanggung jawab dalam penyediaan tabung gas LPG. Tepatnya tanggal 16 Juli 2007 program konversi mulai dilakukan di DKI Jakarta, Tangerang dan Depok. Saat ini PT Pertamina (Persero) mengeluarkan beberapa varian ukuran kemasan produk gas LPG. Dari beberapa varian tabung tersebut, LPG ukuran $3 \mathrm{~kg}$ merupakan subsidi dari pemerintah untuk masyarakat khususnya konsumen rumah tangga dan usaha mikro [1].

Dari data Kementerian Energi dan Sumber Daya Mineral (ESDM) Republik Indonesia pengguna gas LPG ukuran $3 \mathrm{~kg}$ meningkat setiap tahunnya [2], sebagaimana ditampilkan pada Gambar 1. Dengan banyaknya gas LPG ukuran $3 \mathrm{~kg}$, maka perlu halnya perlindungan dan keamanan pengguna tabung LPG ukuran $3 \mathrm{~kg}$ tersebut. PT Pertamina (Persero) juga sudah mempunyai standarisasi tabung gas LPG ukuran $3 \mathrm{~kg}$, dengan cara membuka beberapa bengkel resmi khusus tabung LPG ukuran $3 \mathrm{~kg}$. Salah satunya adalah PT Permatasari Mandiri Jaya. Tabung-tabung yang masuk ke dalam bengkel diidentifikasi, manakah tabung yang mempunyai tampilan buruk, sudah tidak layak pakai, dan tabung mana yang kadaluwarsa [2]. Tabung 
dikatakan memiliki penampilan buruk jika: (1) warna cat buram/pudar, (2) cat mengelupas 20\%, dan (3) logo tabung hilang atau tidak terbaca. Adapun kategori tabung akan tidak layak pakai apabila (1) tidak memenuhi standar keselamatan kerja seperti bocor, valve bocor, valve penyok, bodi penyok, (2) terdapat lekukan, luka atau pelembungan pada dinding tabung, (3) terdapat bekas terbakar pada bodi tabung, (4) terdapat korosi (karat) pada tabung lebih dari 15\% dari luas permukaan tabung, dan (5) kerusakan pada handguard atau footring. Sedangkan tabung kadaluwarsa adalah ketika habis masa edarnya, dilihat dari bulan dan tahun masa berlaku.

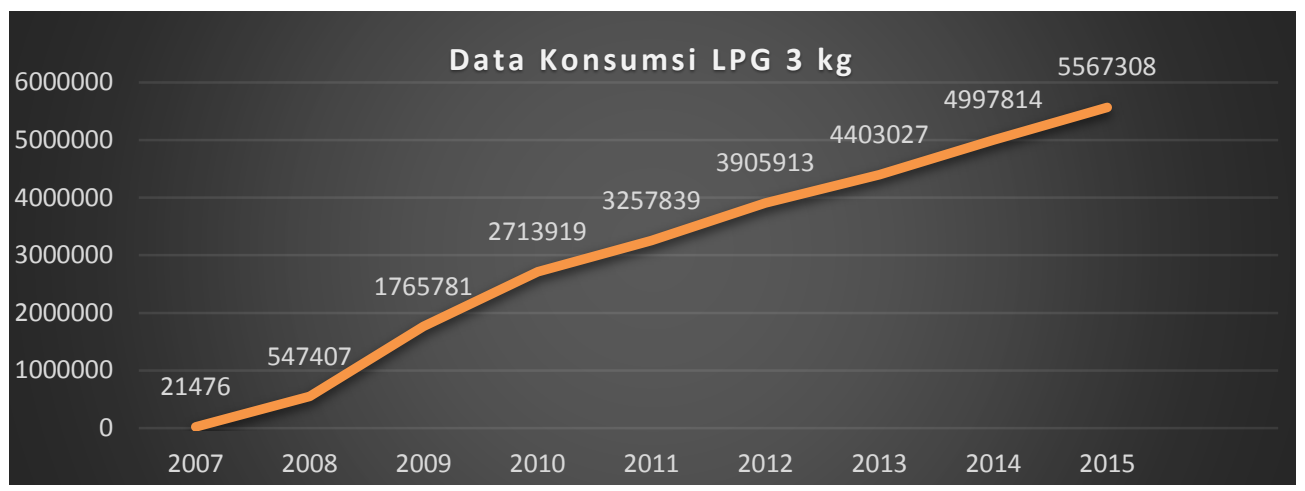

Gambar 1. Data Konsumsi Gas LPG 3 kg tahun 2007-2015 [2].

Identifikasi tabung-tabung LPG $3 \mathrm{~kg}$ dilakukan dengan cara melihat fisik dari tabung-tabung tersebut. Cara ini dapat mengurangi tingkat kualitas dari tabung-tabung LPG 3 kg, dikarenakan setiap orang mempunyai penilaian berbeda-beda.

Subjektivitas terhadap penilaian kelayakan tabung di atas, dapat diminimalkan dengan memanfaatkan pengolahan citra digital. Untuk dapat mengidentifikasi ciri-ciri citra terdapat banyak fitur. Contohnya dalam [3] yang melakukan klasifikasi buah manggis menggunakan fitur RGB. Fitur warna RGB paling dikenal pada perangkat komputer, karena sesuai dengan watak manusia dalam menangkap warna. Ruang warna RGB menggunakan tiga komponen dasar yaitu merah (R), hijau (G), biru (B).

Menurut [4] manusia sebenarnya melihat warna adalah karena cahaya yang dipantulkan objek. Karakteristik persepsi mata manusia dalam membedakan warna satu dan warna lainya berbeda-beda. Semakin berkembangnya zaman, model-model fitur warna bermunculan seperti HSV. Fitur warna ini merupakan format warna alamiah dengan mempertimbangkan pantulan warna, warna sebenarnya, dan kecerahan cahaya.

Penelitian yang dilakukan oleh [5] memanfaatkan metode Color Blob Detection untuk mendapatkan jumlah telur ikan gurami berdasarkan objek yang memiliki warna yang sama dalam bentuk citra HSV yang dikonversikan menjadi RGB. Jumlah telur didapatkan berdasarkan akumulasi banyaknya citra yang memiliki warna yang sama.

Dalam penelitian sebelumnya [6] hasil dari penelitian tingkat akurasinya cukup baik yaitu 76,66\% dengan objek kualitas baik dan 73,33\% dengan kualitas jelek. Penelitian ini mengacu dari klasifikasi warna tabung yang baik yaitu cat mengelupas tidak lebih dari $20 \%$ dan tidak terdapat korosi lebih dari $15 \%$ dari permukaan tabung.

\subsection{Tabung Gas LPG 3 kg}

Gas Liquified Petroleum Gas (LPG) adalah campuran dari berbagai unsur hidrokarbon yang berasal dari gas alam. Dengan menambah tekanan dan menurunkan suhunya, gas berubah menjadi cair. Komponen yang terkandung dalam LPG yaitu propane $\left(\mathrm{C}_{3} \mathrm{H}_{8}\right)$ dan butana $\left(\mathrm{C}_{4} \mathrm{H}_{10}\right)$ [7].

Tabung Gas Liquified Petroleum Gas (LPG) adalah tabung bertekanan yang terbuat dari baja lembaran, pelat, dan gulungan canai panas [2], digunakan untuk menyimpan gas LPG dengan pengisian mulai dari $3 \mathrm{~kg}$ sampai $50 \mathrm{~kg}$. Pada ketentuan Departemen Tenaga Kerja (DEPNAKER) dan PERTAMINA, tabung LPG $3 \mathrm{~kg}$ mempunyai masa berlaku atau masa edarnya yaitu selama 5 tahun sejak bulan tahun pembuatan atau retest terakhir. Masa berlaku tabung dapat dilihat di badan tabung tulisan dan berwarna putih. Ada 3 jenis tabung LPG sesuai dengan kapasitas yaitu ukuran $3 \mathrm{~kg}$ berwarna hijau, $12 \mathrm{~kg}$ berwarna biru, dan $50 \mathrm{~kg}$ berwarna merah. 


\subsection{Citra}

Citra (image) yang berarti gambar. Suatu citra diperoleh dari sebuah objek yang disinari oleh cahaya, dan objek memantulkan kembali cahaya tersebut. Pantulan ini yang ditangkap oleh alat-alat optik seperti mata manusia, kamera dan beberapa alat optik lainnya. Citra mempunyai dua sifat yaitu sifat analog dan sifat digital. Citra yang mempunyai sifat analog tidak dapat diproses oleh komputer karena sifatnya yang kontinu dan berkelanjutan seperti gambar yang tersimpan dalam pita kaset, hasil CT scan dan lain sebagainya. Sedangkan citra yang mempunyai sifat digital dapat diproses oleh komputer [8], sehingga dapat memperoleh nilai-nilai informasi dari citra digital berupa angka. Nilai-nilai angka informasi itu yang nantinya diproses dan menjadi suatu informasi-informasi yang dapat membantu.

Dari nilai-nilai dari citra digital yang diproses, ada beberapa jenis citra digital. Di antaranya adalah citra biner, citra grayscale, dan citra warna (RGB). Citra termasuk biner, jika piksel-pikselnya hanya mempunyai dua buah nilai yaitu hitam dan putih. Nilai dari hitam dengan angka 0 sedangkan putih 1 . Citra grayscale yaitu citra yag mempunyai nilai antara hitam putih atau skala keabuan, misalnya citra 2 bit memiliki empat warna skala keabuan, 3 bit memiliki warna 8 skala keabuan dan seterusnya. Semakin banyak skala keabuanya semakin halus citra grayscale tersebut. Citra warna yaitu citra yang mempunyai kombinasi warna red $(\mathrm{R})$, green $(\mathrm{G})$, dan blue $(\mathrm{B})$. Citra warna atau yang disebut dengan true color karena mempunyai kombinasi warna sebanyak $2^{8} \times 2^{8} \times 2^{8}=16$ juta warna lebih.

\subsection{Model Warna}

Model warna merupakan metode untuk mendeskripsikan suatu citra dengan bermacam nilai. Manusia mendefinisikan warna sesuai kecerahan warna, sedangkan komputer mendefinisikan warna sesuai komponen merah, hijau, dan biru. Model warna biasanya menggunakan tiga parameter untuk mendefinisikan model warna [8]. Beberapa model warna antara lain RGB dan Hue, Saturation, Value (HSV).

Model warna RGB mempunyai tiga layer atau warna dasar yaitu red, green, dan blue. Model warna RGB dapat digambarkan sebuah kubus tiga dimensi. Dari Gambar 2 di bawah, dapat dilihat nilai waran red $=(1,0,0)$, green $=(0,1,0)$, dan blue $=(0,0,1)$.

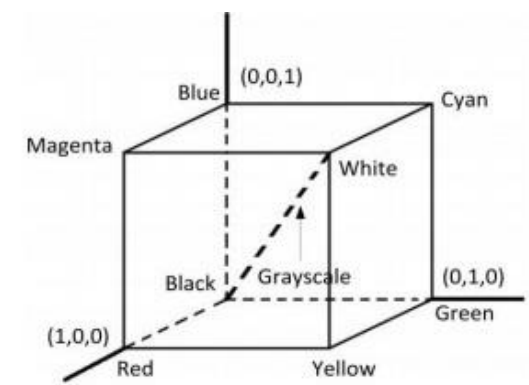

Gambar 2. Skema kubus tiga dimensi RGB [9].

Model warna HSV merupakan model warna yang cara kerjanya paling mendekati dengan mata manusia. Hue merupakan nilai warna asli seperti merah, hijau, biru. Saturation merupakan tingkat kemurnian warna. Value merupakan tingkat kecerahan warna.
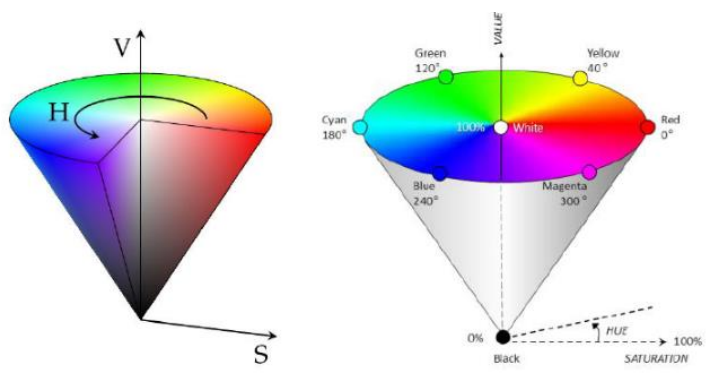

Gambar 3. Skema kubus tiga dimensi RGB [9].

Pada Gambar 3 dapat dilihat dengan koordinat HSV $=\left(0^{\circ}, 0 \%, 0 \%\right)$ merupakan warna hitam. Untuk hijau $\left(120^{\circ}, 100 \%, 100 \%\right)$ dan putih $\left(0^{\circ}, 0 \%, 100 \%\right)$. Nilai rentang hue yaitu berupa sudut antara $0^{\circ}-360^{\circ}$, 
nilai rentang saturation yaitu tingkat kedekatan warna keabuan dari 1\%-100\%, dan untuk value rentangnya sama dengan rentang saturation.

\subsection{Pengolahan Citra Digital}

Pengolahan citra digital (PCD) merupakan bidang ilmu yang mempelajari tentang bagaimana suatu citra itu dibentuk, diolah, dan dianalisis sehingga menghasilkan informasi yang dapat dipahami oleh manusia. Input dari pengolahan citra adalah citra, sedangkan output-nya adalah hasil citra hasil pengolahan. Dalam pengolahan citra digital secara umum, terdapat beberapa tahap. Tahap-tahap pengolahan citra digital dapat dilihat pada Gambar 4.

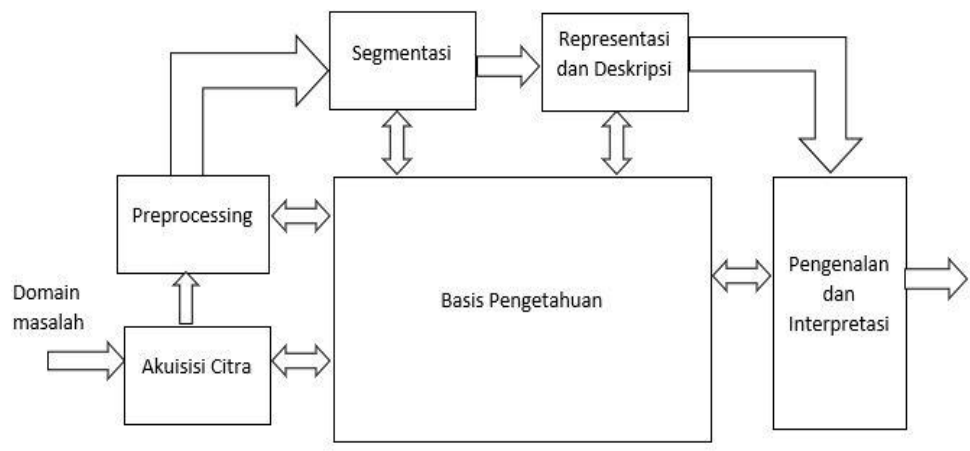

Gambar 4. Tahap-tahap pengolahan citra digital [8].

\subsection{Ekstraksi Fitur}

Ekstraksi fitur merupakan proses untuk mendapatkan nilai karakteristik dari sebuah citra. Nilai karakteristik yang didapatkan akan digunakan sebagai acuan dalam beberapa penelitian PCD. Ekstraksi fitur warna merupakan ekstraksi fitur pada low-level, yaitu berdasarkan visual seperti warna dan tekstur. Penelitian [11] menggunakan ekstraksi fitur warna dari ruang RGB ke HSV. Ruang HSV dapat mendeskripsikan warna dalam citra seperti penglihatan oleh manusia sehingga sangat cocok untuk mengenali warna sesuai mata manusia. Ilustrasi mengenai ekstraksi fitur dan hubungan antara RGB dan HSV disajikan dalam Gambar 5.
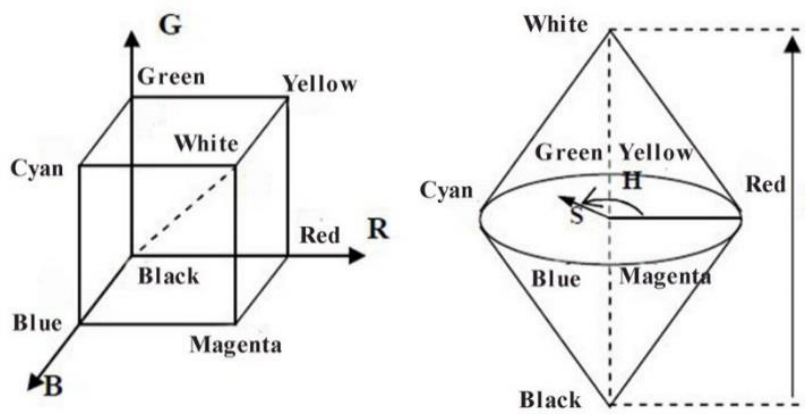

Gambar 5. Hubungan citra RGB dan HSV [11].

Semakin berkembangnya teknologi banyak penelitian menggabungkan ekstraksi fitur warna RGB dan HSV untuk mendapatkan nilai karakteristik yang lebih baik. Seperti penelitian yang dilakukan oleh [9], dalam penelitiannya untuk mendapatkan nilai ektraksi warna dimulai dari konversi citra RGB menjadi citra HSV.

Konversi RGB menjadi HSV dilakukan dengan menggunakan Persamaan 4, 5, 6, dan 7, dengan dinormalisasi terlebih dahulu menggunakan Persamaan 1, 2, dan 3.

$$
\begin{aligned}
& r=\frac{R}{R+G+B} \\
& g=\frac{G}{R+G+B}
\end{aligned}
$$




$$
\begin{gathered}
b=\frac{B}{R+G+B} \\
H=\cos ^{-1}\left[\frac{\frac{1}{2}(2 r-g-b)}{\sqrt{(r-g)^{2}+(r-b)(g-b)}}\right] j i k a b \leq g \\
H=2 \pi-\cos ^{-1}\left[\frac{\frac{1}{2}(2 r-g-b)}{\sqrt{(r-g)^{2}+(r-b)(g-b)}}\right] j i k a b>g \\
S=1-3 \cdot \min (r, g, b) \\
V=\frac{R+G+B}{3}
\end{gathered}
$$

Keterangan rumus:

$$
\begin{array}{ll}
\mathrm{R} & =\text { nilai } \text { red } \text { belum normalisasi } \\
\mathrm{r} & =\text { nilai } \text { red } \text { normalisasi } \\
\mathrm{G} & =\text { nilai } \text { green } \text { belum normalisasi } \\
\mathrm{g} & =\text { nilai } \text { green } \text { normalisasi } \\
\mathrm{B} & =\text { nilai } \text { blue } \text { belum normalisasi } \\
\mathrm{b} & =\text { nilai } \text { blue } \text { normalisasi }
\end{array}
$$

\subsection{Blob Detection}

Ada beberapa teori tentang definisi Blob Detection. Menurut [11] adalah mendeteksi kumpulan titik-titik piksel yang memiliki karakteristik warna yang berbeda bisa lebih terang atau lebih gelap dari latar belakang dan menyatukannya dalam suatu daerah. Menurut [12] adalah sebuah daerah yang terkait setidaknya satu daerah yang ekstrem. Menurut [13] adalah sebuah bujur sangkar dengan daerah yang homogen.

Blob Detection adalah algoritma yang digunakan untuk mengetahui hubungan suatu grup piksel sesuai dengan kategorinya. Metode ini sangat berguna untuk menghitung jumlah dari objek pada suatu citra dan mengidentifikasi objek yang terpisah-pisah pada suatu citra. Pada Blob Detection, citra harus diproses dengan metode ambang terlebih dahulu, berdasarkan warna yang akan dideteksi. Setelah itu, citra dengan warna di atas nilai ambang dapat dikategorikan sesuai dengan aturan yang telah ditentukan terlebih dahulu. Misalnya untuk piksel yang memiliki nilai lebih kecil daripada nilai ambang akan dikelompokkan sebagai komponen dari objek yang dideteksi, sedangkan yang nilainya di atas ambang dikelompokkan sebagai informasi yang tidak penting. Sedangkan untuk mendapatkan titik berat massa adalah dengan merata-ratakan lokasi tiap piksel dengan warna tertentu.

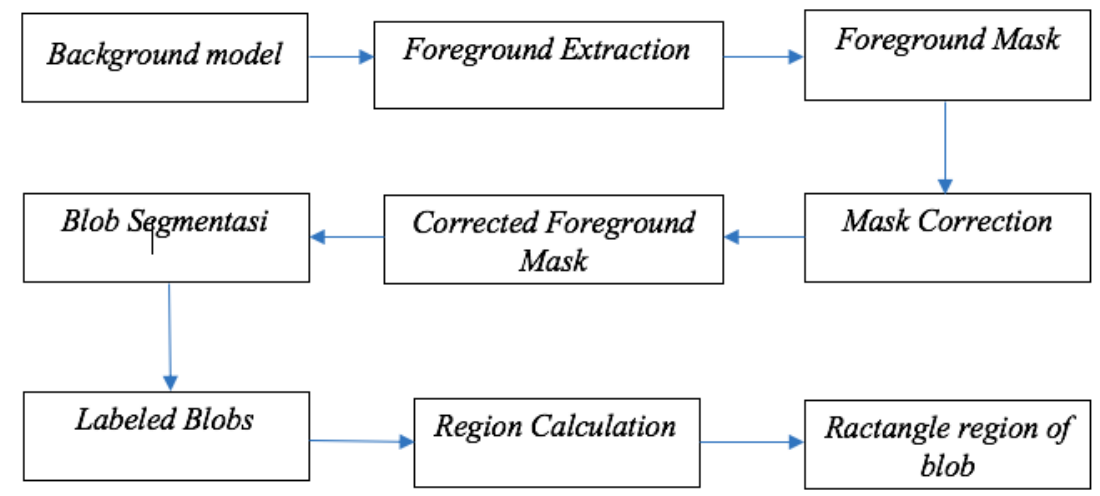

Gambar 6. Langkah umum pada Blob Detection.

Tahap-tahap kerja dari Blob Detection [14] disajikan pada Gambar 6. Selengkapnya adalah sebagai berikut: (1) Background model (model latar belakang) langkah awal untuk menentukan model dari latar belakang dari citra, (2) Foreground Extraction (ekstraksi latar depan) langkah kedua menentukan 
ekstraksi dari latar depan, (3) Foreground Mask (ciri latar depan) setelah menentukan ekstraksi dari latar depan lalu tentukan ciri-ciri dari latar depan, (4) Mask Correction (koreksi ciri) mengoreksi ciri sesuai yang ingin ditetapkan untuk proses berikutnya, (5) Corrected Foreground Mask (koreksi ciri latar depan) mengoreksi latar depan sesuai dengan ciri-ciri yang ditentukan, (6) Blob Segmentation: mengelompokkan ciri-ciri dari latar depan menjadi sebuah gumpalan sesuai dengan kelas nilai cirinya, (7) Labeled Blobs (menandai blob) memberi label pada gumpalan blob, (8) Region Calculation (wilayah perhitungan) menghitung wilayah dari label blob yang sudah dilabel, dan (9) Rectangle region of blob (menentukan wilayah blob) menentukan wilayah dari blob sesuai dengan ciri latar depan sesuai dengan label.

Penggunaan Blob Detection dalam penelitian sudah banyak digunakan. Misalnya penelitian oleh [15] untuk menghitung jumlah ikan nener atau anakan. Penelitian deteksi medis oleh [16], untuk sensor optik [17], dan juga penelitian pendeteksian gerak penghitung kendaraan [18].

\section{Metode Penelitian}

Dalam penelitian ini terdapat dua jenis data yaitu data uji dan data latih. Data yang diambil adalah tabung LPG berukuran $3 \mathrm{~kg}$ langsung dari PT. Permata Mandiri Jaya. Setiap tabung LPG $3 \mathrm{~kg}$ diambil 4 buah gambar untuk 4 tiap sisi tabung. Gambar tabung LPG $3 \mathrm{~kg}$ yang diambil yaitu kualitas baik dan buruk sesuai dengan penilaian manual. Dalam pengambilan gambar tabung LPG $3 \mathrm{~kg}$ menggunakan kamera DSLR dengan memberi latar putih dengan kertas manila. Gambar 7 menunjukkan secara keseluruhan tahap penelitian yang dilakukan.

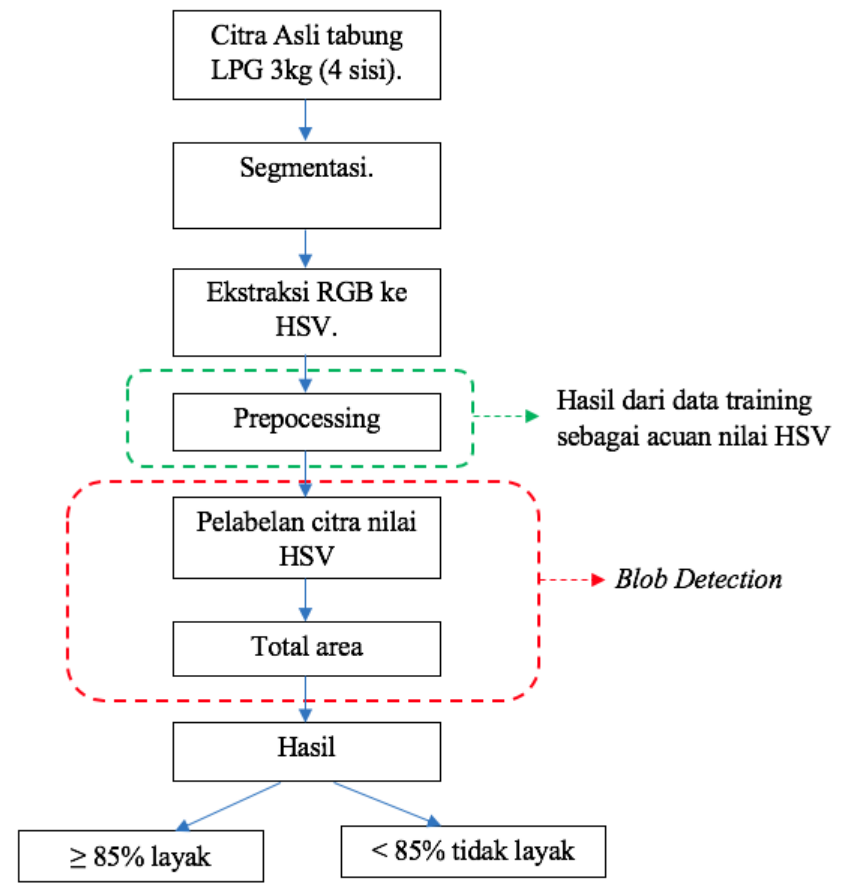

Gambar 7. Tahap-tahap penelitian.

\subsection{Kebutuhan Data Citra}

Data citra yang digunakan dalam penelitian ini terdiri dari dua data citra yaitu data latih dan data uji yang total berjumlah 340 citra dengan format *.jpg. terdapat 160 citra untuk data latih, 60 citra tabung kualitas layak sebelum diperbaiki, 60 citra kualitas layak setelah diperbaiki, dan 60 citra tabung tidak layak. Citra LPG $3 \mathrm{~kg}$ yang digunakan terdiri dari dua kategori yaitu layak dan tidak layak yang masing-masing diambil 4 sisi depan, belakang, kanan, dan kiri. Kategori layak terdapat dua jenis, yaitu tabung setelah dan sebelum diperbaiki. Dalam penelitian ini citra di-resize menjadi 10\% dari nilai aslinya untuk mempermudah komputasi.

Setelah citra diperoleh dilakukan segmentasi untuk memisahkan objek utama dengan gambar latar, kemudian diseragamkan menjadi ukuran 400x400 piksel. Contoh citra yang digunakan pada penelitian ini dapat dilihat pada Tabel 1 . 
Tabel 1. Contoh Citra Penelitian.

\begin{tabular}{llllll}
\hline No & Tabung & Dimensi Asli & $\begin{array}{c}\text { Dimensi } \\
\text { resize }\end{array}$ & $\begin{array}{c}\text { Ukuran } \\
\text { citra asli }\end{array}$ & Ukuran \\
citra resize
\end{tabular}

\subsection{Segmentasi}

Proses identifikasi kelayakan tabung LPG $3 \mathrm{~kg}$ yang diawali dengan proses segmentasi terhadap citra tabung untuk memisahkan objek dengan gambar latar. Proses pertama pemisahan objek yaitu mengekstraksi masing-masing nilai RGB.

\subsection{Ekstraksi RGB to HSV}

Setelah pemisahan objek dengan background selanjutnya objek diekstraksi ke HSV untuk mendapatkan nilai-nilai untuk proses identifikasi. Secara visual, Gambar 8 memperlihatkan hasil proses tersebut.

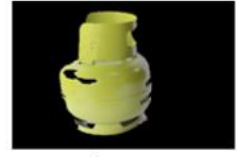

A

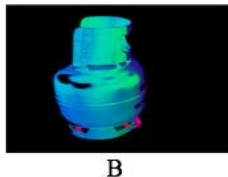

Gambar 8. Konversi dari (A) RGB ke (B) HSV.

Hasil dari proses ini mendapatkan angka minimal dan maksimal HSV sebagai nilai acuan identifikasi tabung. Menggunakan Persamaan 4, 5, 6, dan 7, diperoleh hasil nilai maksimal Hue 83,32 Saturation 88,36\%, dan Value 81,33\%. Sedangkan nilai minimal Hue 51,46 ${ }^{\circ}$, Saturation 11,36\%, dan Value $24,37 \%$.

\subsection{Pelabelan citra nilai HSV}

Proses pelabelan ini menampilkan contoh menggunakan citra LPG $3 \mathrm{~kg}$ dengan kualitas tidak layak dan piksel $5 \times 5$ agar proses pelabelan bisa terlihat dengan jelas, sebagaimana disajikan dalam Gambar 9.

\begin{tabular}{|c|c|c|c|c|}
\hline $82^{0}$ & $82^{0}$ & $81^{0}$ & $81^{0}$ & $83^{0}$ \\
\hline $80^{0}$ & $76^{0}$ & $78^{0}$ & $82^{0}$ & $83^{0}$ \\
\hline $60^{0}$ & $10^{0}$ & $52^{0}$ & $80^{0}$ & $83^{0}$ \\
\hline $22^{0}$ & $347^{0}$ & $52^{0}$ & $80^{0}$ & $83^{0}$ \\
\hline $3^{0}$ & $9^{0}$ & $68^{0}$ & $80^{0}$ & $83^{0}$ \\
\hline
\end{tabular}

A

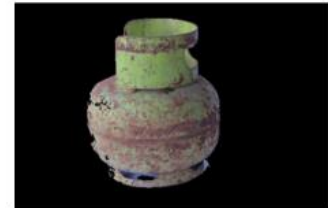

B

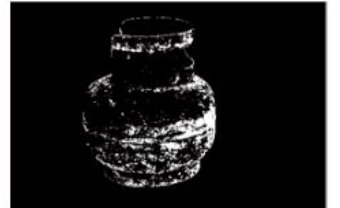

Gambar 9. Hasil dari proses pelabelan antara objek asli (A) dan hasilnya (B).

\subsection{Total Area}

Setelah proses pelabelan selesai selanjutnya hasil pelabelan akan dihitung area warna yang termasuk dalam nilai acuan. Untuk hasil nilai yang di luar acuan akan diubah menjadi warna kuning untuk mempermudah perhitungan. Rumus total area adalah:

$$
\text { Total area }=\frac{\text { area yang sesuai dengan nilai acuan }}{\text { jumlah area }} \times 100 \%
$$

Identifikasi Kualitas Fisik Tabung LPG 3 kg menggunakan Blob Detection dan Fitur Warna RGB to HSV (Erwin Yudi Hidayat) 


\subsection{Identifikasi}

Dalam tahapan identifikasi ini akan dibagi menjadi dua kelas yaitu layak dan tidak layak. Untuk identifikasi layak jika jumlah nilai warna hijau sesuai acuan adalah 85\%-100\% dan untuk identifikasi tidak layak adalah 0\%-84\%. Nilai identifikasi diperoleh dari jumlah total area setiap sisi yang nantinya akan dirata-rata untuk hasil identifikasi. Gambar 10 menyajikan tampilan proses identifikasi yang dimaksud. Di bawah ini merupakan rumus dan perhitungan rata-rata untuk contoh proses identifikasi.

$$
\text { Identifikasi }=\frac{\text { sisi depan }+ \text { sisi belakang }+ \text { sisi kanan }+ \text { sisi kiri }}{4}
$$

$$
\begin{gathered}
\text { Identifikasi }=\frac{72,01 \%+70,83 \%+76,62 \%+78 \%}{4} \\
\text { Identifikasi }=74,36 \% \\
\text { Identifikasi }=\text { tidak layak. }
\end{gathered}
$$

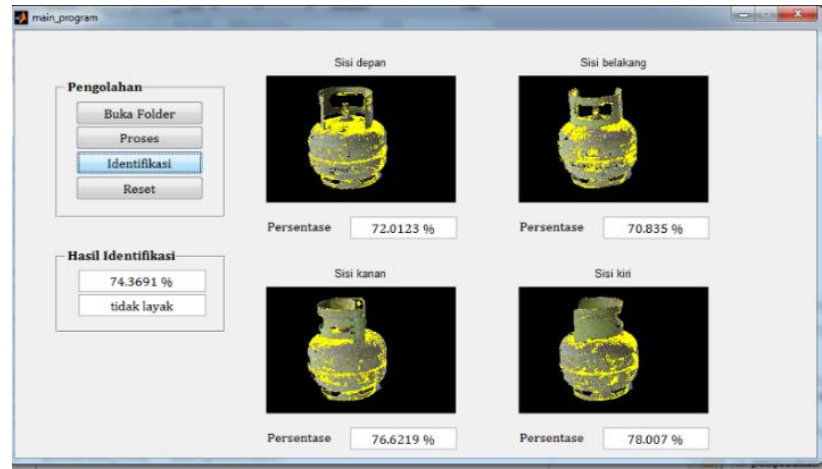

Gambar 10. Contoh proses identifikasi.

\subsection{Pengujian Metode}

Setelah semua data uji diidentifikasi selanjutnya proses pengujian metode yaitu dengan cara menghitung tingkat akurasi dari data testing citra kualitas layak dan citra tidak layak menggunakan rumus sebagai berikut:

$$
\text { Akurasi }=\frac{\text { jumlah data yang diidentifikasi dengan benar }}{\text { jumlah data uji }} \times 100 \%
$$

\section{Hasil dan Pembahasan}

Sebelum dilakukan pengujian, pertama-tama dilakukan dahulu perhitungan menggunakan data latih yang secara keseluruhan berjumlah 160 citra. Citra tersebut diperoleh dari 40 tabung yang keempat sisinya difoto meliputi sisi depan, belakang, kanan, dan kiri.

Tabel 2. Pengujian Citra Kualitas Layak Setelah Tabung Diperbaiki.

\begin{tabular}{cccccccc}
\hline \multirow{2}{*}{ Folder } & \multicolumn{3}{c}{ Persentase Citra Tabung } & \multirow{2}{*}{ Rata-rata } & \multirow{2}{*}{ Identifikasi } & \multirow{2}{*}{ Akurasi } \\
\cline { 2 - 5 } & Depan & Belakang & Kanan & Kiri & & & \\
\hline 1 & $96,97 \%$ & $96,73 \%$ & $99,33 \%$ & $98,49 \%$ & $97,88 \%$ & Layak & Sesuai \\
\hline 2 & $97,32 \%$ & $97,36 \%$ & $99,55 \%$ & $99,01 \%$ & $98,31 \%$ & Layak & Sesuai \\
\hline 3 & $96,89 \%$ & $95,9 \%$ & $99,09 \%$ & $98,28 \%$ & $97,54 \%$ & Layak & Sesuai \\
\hline 4 & $97,15 \%$ & $97,72 \%$ & $98,76 \%$ & $98,61 \%$ & $98,06 \%$ & Layak & Sesuai \\
\hline 5 & $97,49 \%$ & $97,61 \%$ & $99,42 \%$ & $99,42 \%$ & $98,48 \%$ & Layak & Sesuai \\
\hline 6 & $97,48 \%$ & $96,12 \%$ & $98,78 \%$ & $98,77 \%$ & $97,79 \%$ & Layak & Sesuai \\
\hline 7 & $96,74 \%$ & $96,13 \%$ & $98,45 \%$ & $98,68 \%$ & $97,5 \%$ & Layak & Sesuai \\
\hline 8 & $96,31 \%$ & $96,54 \%$ & $98,57 \%$ & $98,87 \%$ & $97,57 \%$ & Layak & Sesuai \\
\hline 9 & $97,05 \%$ & $96,21 \%$ & $98,44 \%$ & $98,63 \%$ & $97,58 \%$ & Layak & Sesuai \\
\hline 10 & $97,47 \%$ & $97,37 \%$ & $98,61 \%$ & $98,36 \%$ & $97,95 \%$ & Layak & Sesuai \\
\hline 11 & $97,5 \%$ & $96,08 \%$ & $98,65 \%$ & $98,79 \%$ & $97,75 \%$ & Layak & Sesuai \\
\hline 12 & $97,35 \%$ & $96,5 \%$ & $99,12 \%$ & $98 \%$ & $97,74 \%$ & Layak & Sesuai \\
\hline 13 & $97,31 \%$ & $97,51 \%$ & $98,76 \%$ & $98,54 \%$ & $98,03 \%$ & Layak & Sesuai \\
\hline 14 & $97,82 \%$ & $96,86 \%$ & $98,71 \%$ & $98,53 \%$ & $97,98 \%$ & Layak & Sesuai \\
\hline 15 & $97,1 \%$ & $96,18 \%$ & $98,62 \%$ & $98,41 \%$ & $97,68 \%$ & Layak & Sesuai \\
\hline
\end{tabular}


Pengujian pertama menggunakan data uji dengan citra kualitas layak dengan total sebanyak 60 citra, meliputi citra sisi depan, belakang, kanan, dan kiri, dari 15 tabung. Citra tabung yang diambil merupakan tabung LPG $3 \mathrm{~kg}$ yang selesai diperbaiki di PT Permata Mandiri Jaya. Hasil akurasi untuk pengujian pertama dapat dilihat di Tabel 2. Persentase terendah untuk sisi depan adalah 96,31\% pada tabung ke-8 dan tertinggi $97,82 \%$ pada tabung ke-14. Pada sisi belakang, tabung nomor 3 menempati urutan terbawah dengan 95,9\% dan tertinggi yaitu 97,72\% pada tabung ke-4. Persentase terendah pada sisi kanan tabung sebesar $98 \%$ untuk tabung ke-12, dan tertinggi 99,55\% pada tabung ke-2. Dari sisi kiri, angka 97,5\% pada tabung nomor 7 tercatat sebagai nilai terendah, dan $99,42 \%$ pada tabung nomor 5 sebagai nilai tertinggi. Rata-rata persentase citra tabung tertinggi yaitu 98,48\% pada tabung nomor 5, dan terendah 97,5\% pada tabung ke-7.

Hasil dari akurasi pengujian menggunakan citra tabung kualitas layak setelah tabung diperbaiki yaitu $100 \%$ dengan rata-rata nilai akurasi 97\%-98\%. Terdapat kesesuaian antara seluruh citra yang diuji dengan seluruh citra yang dilatih. Angka tersebut diperoleh karena citra yang digunakan adalah citra yang tanpa ada korosi pada permukaan tabung.

Hasil akurasi untuk pengujian kedua dengan citra tabung kualitas layak yang belum diperbaiki disajikan di Tabel 3. Pengujian ini menggunakan data uji dengan citra kualitas layak, namun sebelum tabung diperbaiki. Tabung yang digunakan sejumlah 15, yang keempat sisinya diambil masing-masing satu citra yang mewakili. Persentase citra tabung dari sisi depan tercatat 74,31\% pada tabung ke-11 sebagai nilai terendah, dan $87,91 \%$ pada tabung ke-5 sebagai hasil tertinggi. Dari sisi belakang, tabung nomor 11 dengan $77,4 \%$ dinyatakan sebagai yang terendah, dan $87,33 \%$ dari tabung ke-10 sebagai yang paling baik. Adapun untuk hasil tertinggi dan terendah dari sisi kanan adalah sebesar 89,38\% dan 79,19\% dari tabung pertama dan ke-3. Sedangkan untuk sisi kiri tabung, citra dari tabung ke-11 sebesar $77,81 \%$ menduduki peringkat terbawah, dan citra pertama menempati hasil terbaik dengan $88,41 \%$. Rata-rata tertinggi ditemukan pada tabung ke-1 dengan $87,78 \%$ dan terendah $77,81 \%$ pada tabung ke- 11 .

Tabel 3. Pengujian Citra Kualitas Layak Sebelum Tabung Diperbaiki.

\begin{tabular}{cccccccc}
\hline \multirow{2}{*}{ Folder } & \multicolumn{3}{c}{ Persentase Citra Tabung } & \multirow{2}{*}{ Rata-rata } & \multirow{2}{*}{ Identifikasi } & \multirow{2}{*}{ Akurasi } \\
\cline { 2 - 5 } & Depan & Belakang & Kanan & Kiri & & \\
\hline 1 & $86,67 \%$ & $86,34 \%$ & $89,38 \%$ & $88,41 \%$ & $87,78 \%$ & Layak & Sesuai \\
\hline 2 & $80,75 \%$ & $86,68 \%$ & $84,5 \%$ & $83,9 \%$ & $83,95 \%$ & Tidak Layak & Tidak Sesuai \\
\hline 3 & $76,37 \%$ & $86,91 \%$ & $79,19 \%$ & $78,23 \%$ & $80,17 \%$ & Tidak Layak & Tidak Sesuai \\
\hline 4 & $86,85 \%$ & $85,23 \%$ & $88,16 \%$ & $85,71 \%$ & $86,49 \%$ & Layak & Sesuai \\
\hline 5 & $87,91 \%$ & $83,78 \%$ & $86,67 \%$ & $85,21 \%$ & $85,89 \%$ & Layak & Sesuai \\
\hline 6 & $84,27 \%$ & $86,12 \%$ & $88,57 \%$ & $83,37 \%$ & $85,58 \%$ & Layak & Sesuai \\
\hline 7 & $86,74 \%$ & $83,31 \%$ & $84,54 \%$ & $85,88 \%$ & $85,12 \%$ & Layak & Sesuai \\
\hline 8 & $83,11 \%$ & $86,24 \%$ & $85,76 \%$ & $84,07 \%$ & $84,78 \%$ & Tidak Layak & Tidak Sesuai \\
\hline 9 & $87,5 \%$ & $86,17 \%$ & $84,34 \%$ & $85,86 \%$ & $85,97 \%$ & Layak & Sesuai \\
\hline 10 & $84,72 \%$ & $87,33 \%$ & $86,69 \%$ & $85,16 \%$ & $85,98 \%$ & Layak & Sesuai \\
\hline 11 & $74,31 \%$ & $77,4 \%$ & $79,65 \%$ & $79,88 \%$ & $77,81 \%$ & Tidak Layak & Tidak Sesuai \\
\hline 12 & $85,35 \%$ & $86,28 \%$ & $84,54 \%$ & $85,92 \%$ & $85,52 \%$ & Layak & Sesuai \\
\hline 13 & $84,79 \%$ & $86,11 \%$ & $87,76 \%$ & $83,7 \%$ & $85,59 \%$ & Layak & Sesuai \\
\hline 14 & $87,84 \%$ & $86,6 \%$ & $88,17 \%$ & $86,55 \%$ & $87,29 \%$ & Layak & Sesuai \\
\hline 15 & $86,14 \%$ & $86,61 \%$ & $85,68 \%$ & $87,45 \%$ & $86,47 \%$ & Layak & Sesuai \\
\hline
\end{tabular}

Hasil dari akurasi pengujian menggunakan citra tabung kualitas layak sebelum diperbaiki yaitu $73,33 \%$. Terdapat 4 citra yaitu tabung nomor 2, 3, 8, dan 11 yang tidak sesuai dengan akurasi dengan nilai rata-rata 77\%-84\%. Hal ini diakibatkan karena lebih banyak tingkat korosi pada permukaan tabung. Sedangkan 11 citra tabung lainnya dinyatakan sesuai dengan akurasi dengan rata-rata $85 \%-88 \%$.

Tabel 4. Pengujian Citra Kualitas Tidak Layak

\begin{tabular}{|c|c|c|c|c|c|c|c|}
\hline \multirow{2}{*}{ Folder } & \multicolumn{4}{|c|}{ Persentase Citra Tabung } & \multirow{2}{*}{ Rata-rata } & \multirow{2}{*}{ Identifikasi } & \multirow{2}{*}{ Akurasi } \\
\hline & Depan & Belakang & Kanan & Kiri & & & \\
\hline 1 & $71,65 \%$ & $76,14 \%$ & $84,82 \%$ & $81,74 \%$ & $78,59 \%$ & Tidak Layak & Sesuai \\
\hline 2 & $89,25 \%$ & $82,22 \%$ & $86,87 \%$ & $81,75 \%$ & $85,02 \%$ & Layak & Tidak Sesuai \\
\hline 3 & $74,07 \%$ & $71,65 \%$ & $77,58 \%$ & $73,29 \%$ & $74,15 \%$ & Tidak Layak & Sesuai \\
\hline 4 & $89,27 \%$ & $82,21 \%$ & $89,09 \%$ & $87,55 \%$ & $87,03 \%$ & Layak & $\overline{\text { Tidak Sesuai }}$ \\
\hline 5 & $73,44 \%$ & $67,86 \%$ & $74,42 \%$ & $61,89 \%$ & $69,4 \%$ & Tidak Layak & Sesuai \\
\hline 6 & $72,01 \%$ & $70,83 \%$ & $76,63 \%$ & $78 \%$ & $74,46 \%$ & Tidak Layak & Sesuai \\
\hline 7 & $71,36 \%$ & $65,13 \%$ & $78,39 \%$ & $64,87 \%$ & $69,94 \%$ & Tidak Layak & Sesuai \\
\hline 8 & $62,53 \%$ & $58,59 \%$ & $67,21 \%$ & $60,37 \%$ & $62,17 \%$ & Tidak Layak & Sesuai \\
\hline 9 & $67,62 \%$ & $66,53 \%$ & $73,53 \%$ & $70,63 \%$ & $69,58 \%$ & Tidak Layak & Sesuai \\
\hline
\end{tabular}

Identifikasi Kualitas Fisik Tabung LPG 3 kg menggunakan Blob Detection dan Fitur Warna RGB to HSV (Erwin Yudi Hidayat) 


\begin{tabular}{|c|c|c|c|c|c|c|c|}
\hline \multirow{2}{*}{ Folder } & \multicolumn{4}{|c|}{ Persentase Citra Tabung } & \multirow{2}{*}{ Rata-rata } & \multirow{2}{*}{ Identifikasi } & \multirow{2}{*}{ Akurasi } \\
\hline & Depan & Belakang & Kanan & Kiri & & & \\
\hline 10 & $75,17 \%$ & $71,08 \%$ & $74,55 \%$ & $76,86 \%$ & $74,41 \%$ & Tidak Layak & Sesuai \\
\hline 11 & $79,61 \%$ & $67,39 \%$ & $77,09 \%$ & $74,96 \%$ & $74,76 \%$ & Tidak Layak & Sesuai \\
\hline 12 & $79,61 \%$ & $71,07 \%$ & $74,55 \%$ & $87,55 \%$ & $78,2 \%$ & Tidak Layak & Sesuai \\
\hline 13 & $71,65 \%$ & $67,62 \%$ & $77,58 \%$ & $70,63 \%$ & $71,87 \%$ & Tidak Layak & Sesuai \\
\hline 14 & $82,21 \%$ & $71,36 \%$ & $89,11 \%$ & $81,28 \%$ & $80,99 \%$ & Tidak Layak & Sesuai \\
\hline 15 & $88,26 \%$ & $78,77 \%$ & $76,63 \%$ & $81,29 \%$ & $81,48 \%$ & Tidak Layak & Sesuai \\
\hline
\end{tabular}

Pengujian ketiga menggunakan data uji dengan citra kualitas tidak layak. Sebanyak 60 citra tabung yang diambil merupakan tabung LPG $3 \mathrm{~kg}$ yang sudah dikelompokkan untuk diperbaiki kondisi fisiknya. Hasil akurasi untuk pengujian ketiga akurat dapat dilihat di Tabel 4. Persentase terendah untuk sisi depan, belakang, kanan, dan kiri secara berturut-turut adalah 62,53\%, 58,59\%, 67,21\%, dan 62,17\% pada tabung ke-8. Sedangkan persentase tertinggi dari sisi yang sama yaitu $89,27 \%$ dan $82,2 \%$ pada tabung nomor 2 , $89,11 \%$ pada tabung ke-14, serta $87,55 \%$ pada tabung ke-4 dan ke- 12 . Nilai rata-rata $87,03 \%$ pada tabung nomor 4 dicatat sebagai hasil tertinggi, dan $62,17 \%$ pada tabung ke- 8 sebagai yang paling rendah.

Hasil dari akurasi pengujian menggunakan citra tabung kualitas tidak layak yaitu 86,67\%. Terdapat 2 citra tabung dengan nomor 2 dan 4 yang tidak sesuai dengan akurasi. Sedangkan 13 citra tabung sesuai dengan akurasi dengan rata-rata 69\%-80\% dikarenakan terdapat banyak korosi di bagian tabung.

\section{Kesimpulan}

Dari segi warna, tabung dikatakan layak jika tidak terdapat korosi karat lebih dari $15 \%$. Identifikasi kelayakan fisik tabung dapat dilakukan dengan metode Blob Detection dan ekstraksi RGB to HSV, menjadi kelas layak dan tidak layak dengan tepat. Hasil akurasi identifikasi telah dilakukan dengan data uji masingmasing kualitas berjumlah 15 citra. Hasil akurasi untuk data uji citra berkualitas layak setelah tabung diperbaiki diperoleh 100\%. Data uji citra berkualitas layak sebelum tabung diperbaiki diperoleh 73,33\% sesuai dengan kriteria layak, dengan 4 citra tabung tidak masuk kriteria layak. Sedangkan untuk data uji kualitas tidak layak hasil akurasinya 86,67\%, karena terdapat 2 citra tabung LPG $3 \mathrm{~kg}$ masuk ke dalam kriteria layak.

\section{Daftar Pustaka}

[1] I. Wiratmaja, "Kebijakan LPG 3KG," Kementerian ESDM Republik Indonesia, Jakarta, 2016.

[2] F. Febrianto, B. Busama and G. Widyaputra, "Standarisasi Sarana Fasilitas dan Pedoman Oprasional Bengkel Pemeliharaan Tabung LPG," PT Pertamina (Persero), Jakarta, 2016.

[3] R. Kastaman and Marsetyo, "Aplikasi Pengolah Citra dengan Basis Warna "RGB" Untuk Klasifikasi Buah Manggis," Jurnal Bionatura, vol. 10, no. 5, pp. 273 - 291, 2008.

[4] A. Susanto and A. Kadir, "Teori dan Aplikasi Pengolahan Citra", Yogyakarta: Andi, 2013.

[5] M. T. Setiawan and K. Firdausy, "Aplikasi Penghitung Telur Ikan Gurami menggunakan Deteksi Bloob berbasis Android," in Seminar Nasional Aplikasi Teknologi Informasi (SNATI), Yogyakarta, 2016.

[6] M. J. Fathoni, "Pengolahan Citra untuk Mengidentifikasi kualitas Fisik Tabung LPG Ukuran 3KG Berbasis Bentuk," Gresik, 2013.

[7] Badan Standarisasi Nasional, "Tabung Baja LPG," Badan Standarisasi Nasional, Jakarta, 2011.

[8] P. N. Andono and T. Sutojo, Konsep Pengolahan Citra Digital, Yogyakarta: Andi, 2015.

[9] E. Budianita, J. Jasril and L. Handayani, "Implementasi Pengolahan Citra dan Klasifikasi K-Nearest Neighbour untuk Membangun Aplikasi Pembeda Daging Sapi dan Babi," Jurnal Sains, Teknologi, dan Industri (SiTekIn), vol. 12, no. 2, pp. 242 - 247, 2015.

[10] Kaspers, "Blob Detection," in Presented at the Biomedical Image Sciences, Image Sciences Institute, UMC Utrecht, 2011.

[11] R. C. Gonzalez and E. Woods, Digital Image Processing, Upper Saddle River, New Jersey: Prentice Hall, 2002.

[12] T. Lindeberg, "Detecting salient blob-like image structures and their scales with a scale-space primal sketch: A method for focus-of-attention," International Journal of Computer Vision, vol. 11, no. 3 , pp. 283-318, 1993.

[13] S. Hinz, "Fast and Subpixel Precise Blob Detection and Attribution," in IEEE International Conference on Image Processing, Genova, 2005. 
[14] T. B. Nguyen and S. T. Chung, "An Improved Real-Time Blob Detection for Visual Surveillance," in 2nd International Congress on Image and Signal Processing, Tianjin, 2009.

[15] R. S. Sinukun, "Identifikasi Jumlah Citra Nener Menggunakan Metode Blob," Prosiding Seminar Nasional Aplikasi Sains \& Teknologi (SNAST), 15 November 2014.

[16] J. Liu, J. M. White and R. M. Summers, "Automated Detection of Blob Structures by Hessian Analysis and Object Scale," in IEEE International Conference on Image Processing, Hong Kong, 2010.

[17] N. Azami, D. El Idrissi, S. Amrane and M. Harmouchi, "Computer Blob Detection and Tracking for Highly Repeatable Optical Fiber Sensor," in International Conference on Intelligent Systems: Theories and Applications, Rabat, 2014.

[18] D. Kiran, A. I. Rasheed and H. Rasamangu, "FPGA Implementation of Blob Detection Algorithm for Object Detection in Visual Navigation," in International conference on Circuits, Controls and Communications, Bengaluru, 2014 